\title{
Prospek Pelestarian Dan Pengembangan Bangunan Pesanggrahan
}

\section{Sambung Widodo}

Keywords: cultural resource management, islam, kraton, utilization, protection, conservation

\section{How to Cite:}

Widodo, S. (2003). Prospek Pelestarian Dan Pengembangan Bangunan Pesanggrahan. Berkala Arkeologi, 23(2), 101-113. https://doi.org/10.30883/iba.v23i2.878

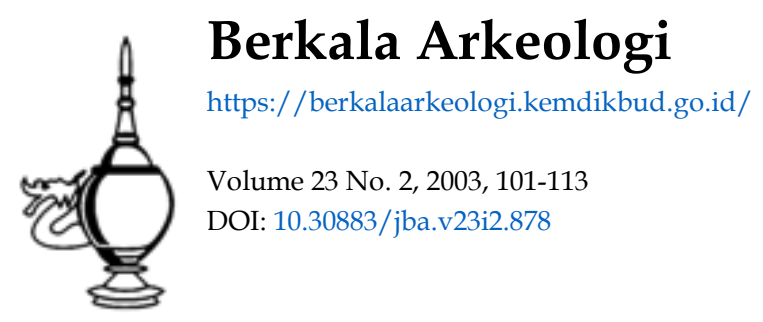

\section{(c) (1) (2) (2)}

This work is licensed under a Creative Commons Attribution-NonCommercial-ShareAlike 4.0 International License. 


\title{
PROSPEK PELESTARIAN DAN PENGEMBANGAN BANGUNAN PESANGGRAHAN
}

\author{
Sambung Widodo
}

\section{$\mathbf{P}$}

\section{ENDAHULUAN}

\section{A. Permasalahan.}

Kasultanan Yogyakarta maupun di wilayah Kasunanan Surakarta. Taman (pesanggrahan) sebagai tempat peristirahatan erat kaitannya dengan kraton, karena pada umumnya dibuat oleh dan untuk raja beserta kerabatnya. Mengingat fungsinya yang berhubungan ketenangan, rekreasi, peristirahatan dan pertahanan. Bangunan pesanggrahan dibuat dengan memperhatikan privasi. Secara fisik bangunan pesanggrahan umumnya dilengkapi dengan taman, petirtaan, tempat untuk beristirahat dan tempat untuk bermiditasi. Tetapi bangunan pesanggrahan dapat pula dipergunakan sebagai tempat pertahanan, sebagai contoh bangunan pesanggrahan Tamansari, pesanggrahan Segoroyoso yang terdapat di wilayah kraton Kasultanan Yogyakarta dan pesanggrahan Sunyaragi yang terdapat di Kraton Cirebon (Sulendraningrat, 1978). Berdasarkan analisis terhadap komponen-komponen/unsur-unsur bangunan bekas bangunan pesanggrahan yang terdapat di wilayah kraton Kasultanan Yogyakarta dan di wilayah kraton Kasunan Surakarta, tampak adanya tiga kelompok bekas bangunan pesanggrahan pada masa Mataram Islam. Kelomopok pertama bangunan-bangunan pesanggrahan dengan komponen bangunan berupa bangunan Taman, Pendopo, bangunan Pringgitan, bangunan Dalem Ageng, bangunan tempat meditasi dan kolam. Kelompok kedua, adalah bangunan pesanggrahan dengan komponen-komponen /unsur-unsur bangunan Taman, bangunan Kolam, bangunan tempat meditasi (ibadah), bangunan lorong-lorong bawah tanah. Ketiaga, bangunanbangunan pesanggrahan dengan komponen-komponen/unsur-unsur bangunan berupa Tempat tinggal, bangunan Kolam dan bangunan Taman.

Bangunan-bangunan pesanggrahan dengan komponen-komponen/unsur-unsur bangunan berupa Taman, bangunan Pendopo, bangunan Pringgitan, bangunan Dalem Ageng, bangunan tempat meditasi (ibadah) dan bangunan Kolam yang terdapat di wilayah Kasultanan Yogyakarta adalah meliputi pesanggrahan Ambarukmo dan pesanggrahan Ambarbinangun. Sedangkan di wilayah Kasunanan Surakarata meliputi, pesanggrahan Paras dan pesanggrahan Procimoharjo.

Bangunan-bangunan pesanggrahan di wilayah Kasultanan Yogyakarta dengan komponen-komponen/unsur-unsur bangunan berupa Taman, bangunan kolam, bangunan tempat meditasi (ibadah), bangunan lorong-lorong bawah tanah , misalnya bangunan pesanggrahan Tamansari dan pesanggrahan Gua Siluman. 
Bangunan pesanggrahan dengan komponen-komponen/unsur-unsur bangunan berupa bangunan Tempat tinggal, bangunan Kolam dan bangunan Taman yang terdapat di wilayah Kasultanan Yogyakarta adalah pesanggrahan Purworejo dan pesanggrahan Warungboto. Sedangkan di wilayah Kasunanan Surakarta adalah pesanggrahan Kebon Rojo dan pesanggrahan Balekambang.

Munculnya bangunan-bangunan pesanggrahan baik yang berada di wilayah Kasultanan Yogyakarta maupun di wilayah Kasunanan Surakarta yang berfungsi sebagai tempat rekreasi, peristirahatan, meditasi dan pertahanan. Tentunya tidak terlepas juga dengan keadaan sosial politik pada masa itu, yaitu bahwa dengan adanya perjanjian Gianti tahun 1755 M kerajaan Mataram Islam dibagi dua, yaitu menjadi Kasultanan Yogyakarta dan Kasunanan Surakarta (Soekanto, 1952). Pembagian ini dilakukan dengan sungguh - sungguh dalam arti kedua belah pihak meminta supaya bagian masing - masing betul - betul sama besarnya. Akibatnya ialah letak daerah Sultan dan Sunan tak teratur, tanah-tanah Sultan terletak di dalam tanah Sunan dan sebaliknya tanah-tanah Sunan terletak di dalam tanah Sultan. Akibatnya tak mungkin menjalankan kepolisian yang teratur oleh karena penjahat-penjahat mudah melarikan diri dari daerah Sunan ke daerah Sultan dan sebaliknya. Ini mengakibatkan sering terjadi pertikaian diperbatasan-perbatasan antara kerajaan Sunan dan kerajaan Sultan.

Selain adanya beberapa hal tersebut di atas, disebutkan juga dari beberapa sumber sejarah yang mencatat adanya berbagai perlawanan ataupun adanya beberapa pemberontakan yang terjadi antara rakyat dengan penguasa pada masa pemerintahan Sri Sultan Hamengku Buwono I, yaitu antara lain pemberontakan yang terjadi di Gunungkidul yang dipimpin oleh Ki Setyoyuda (Soekanto,1952.).

Adanya kegentingan-kegentingan diperbatasan antara Kasultanan Yogyakarta dan Kasunanan Surakarta juga terjadinya pemberontakan-pemberontakan pada waktu itu, membuat para raja baik di Kasultanan Yogaykarta maupun di Kasunanan Surakarta mendirikan bangunan-bangunan pesanggrahan yang berfungsi selain sebagai tempat rekreasi, peristirahatan, religius juga berfungsi sebagai pertahanan.

Persebaran maupun fungsi sejumlah bangunan pesanggrahan baik yang berada di wilayah Keraton Kasultanan Yogyakarta maupun di wilayah Kasunanan Surakarta. Baik yang masih tampak data fisiknya maupun yang hanya tersisa namanya saja, terlihat bahwa beberapa faktor telah menjadi bahan pertimbangan dalam memilih lokasi maupun dalam memfungsikan bangunan-bangunan pesanggrahan yang ada. Faktor strategis misalnya, terlihat pada pemilihan lokasi pendirian bangunanbangunan pesanggrahan yang difungsikan sebagai sarana pertahanan, peristirahatan, rekreasi dan religius. Biasanya bangunan pesanggrahan semacam ini di bangun dengan mempertimbangkan intensitas ancaman yang datang, misalnya pesanggrahan Ambaruko yang terdapat di wilayah Kasultanan Yogyakarta, kemungkinan 
pesanggrahan ini dibangun selain mempunyai fungsi untuk rekreasi dan peristirahatan juga berfungsi untuk pertahanan yaitu berfungsi untuk mengawasi jalan utama yang pada waktu itu menghubungkan antara dua kerajaan (Kasultanan Yogyakarta dan Kasunanan Surakarta). Karena setelah pasca perjanjian Gianti tahun 1755 M yang membagi Kerajaan Mataram Islam menjadi dua yaitu menjadi Kasultanan Yogyakarta dan Kasunanan Surakarta sering terjadi ketegangan politik diantara kedua kerajaan tersebut. Demikian pula bangunan pesanggrahan Purwodadi yang terdapat di wilayah Kasunanan Surakarta didirikan (di tempat) pada bagian jalur utama yang menghubungkan antara kraton Kasunanan Surakarta dan Kasultanan Yogyakarta. Dari berbagai contoh tersebut di atas dapat dikatakan bahwa intensitas ancaman yang terjadi pada masa itu telah di antisipasi baik oleh Sultan maupun Sunan dalam persebaran dan fungsi pendirian bangunan-bangunan pesanggrahan tersebut. Sedangkan untuk bangunan-bangunan pesanggrahan yang difunsikan hanya sebagai tempat peristirahatan, rekreasi dan religius diletakkan pada lokasi-lokasi yang relatif tersembunyi.

Dibeberapa wilayah Kasultanan Yogyakarta maupun diwilayah Kasunanan Surakarta bekas bangunan-bangunan pesanggrahan masih dapat disaksikan hingga kini dalam jumlah yang begitu banyak dengan bentuk maupun keletakan yang beragam. Bangunan-bangunan pesanggrahan tersebut merupakan salah satu jenis tinggalan Arkeologis pada masa kerajaan Mataram Islam yang memiliki keterkaitan erat dengan sejarah bangsa Indonesia, dan selain itu dengan mengacu UU RI No. 5/1992 diketahui bahwa bangunan-bangunan pesanggrahan tersebut juga merupakan salah satu Benda Cagar Budaya (BCB). Meskipun termasuk dalam kategori BCB, namun pada kenyataannya sebagian besar bangunan-bangunan pesanggrahan tersebut belum diperlakukan sebagai BCB karena berbagai sebab.

Dalam makalah ini akan dipaparkan mengenai keberadaan dan kondisi fisik sejumlah bangunan-bangunan pesanggrahan di wilayah Keraton Kasultanan Yogyakarta maupun diwilayah Keraton Kasunanan Surakarta. Penyajian ini di dasarkan atas fakta yang dijumpai di lapangan sebagai realisasi dari penelitian yang telah dilakukan oleh Balai Arkeologi Yogyakarta di DIY dan Jawa Tengah dalam tahun 2000-2002 (Widodo, 2001/2002).

\section{B. Maksud dan Tujuan.}

kajian tentang aspek kelestarian bangunan pesanggrahan dari masa Kerajaan Mataram Islam ini dilandasi dengan tujuan untuk mengimformasikan kondisi sejumlah bangunan pesanggrahan tersebut saat ini. Selain itu juga akan disinggung mengenai potensi yang terkandung di dalamnya. Melalui penyajian ini diharapkan diperoleh gambaran langkah yang sebaiknya dilakukan dalam mengupayakan pelestarian 
maupun pemanfaatan yang mungkin dapat diterapkan pada bangunan-bangunan pesanggrahan tersebut.

\section{T EBERADAAN DAN KONDISI BANGUNAN-BANGUNAN PESANGGRAHAN DI WILAYAH KERATON KASULTANAN YOGYAKARTA DAN KASUNANAN SURAKARTA}

Bekas bangunan pesanggrahan yang menjadi obyek bahasan berjumlah 15 buah yang masing-masing terdapat di wilayah Kasultanan Yogyakarta berjumlah 9 buah dan di wilayah Kasunanan Surakarta berjumlah 6 buah. Dari 15 buah bangunan pesanggrahan yang ada, diantaranya merupakan bangunan pesanggrahan yang berfungsi sebagai tempat peristirahatan, rekreasi dan religius berjumlah 8 buah dan merupakan bangunan pesanggrahan berfungsi sebagai tempat peristirahatan dan rekreasi 5 buah. Serta lainnya merupakan bangunan pesanggrahan yang berfungsi sebagai tempat rekreasi, peristirahatan, religius dan pertahanan. Sejumlah bangunan pesanggrahan kondisinya sampai saat ini ada yang relatif masih utuh sementara beberapa diantarannya sudah rusak.

\section{A. Bangunan pesanggrahan di wilayah Kasultanan Yogyakarta}

\section{Pesanggrahan Gua Siluman}

Pesanggrahan Gua Siluman, terletak di Kalurahan Banguntapan, Desa Wonocatur Kabupaten Bantul, Propinsi D.I.Y. Pesanggrahan Gua Siluman didirikan pada masa pemerintahan Sri Sultan Hamengku Buwono II (1792-1810). Secara keseluruhan bangunan pesanggrahan Gua Siluman berupa lorong berbentuk $L$ dengan bangunan di bagian belakang berpintu tiga, masing-masing menghadap ke barat, selatan dan timur. Pada bagian belakang bangunan pesanggrahan terdapat kolam berbentuk empat persegi panjang. Keadaan pesanggrahan Gua Siluman pada saat ini sudah banyak mengalami kerusakan.

\section{Pesanggrahan Warungboto}

Pesanggrahan Warungboto, terletak di Desa Warungboto, Kecamatan Umbulharjo, Kodia Yogyakarta. Pesanggrahan Warungboto pada hakekatnya merupakan sumber air yang kemudian dibuat menjadi tempat pesanggrahan sekaligus tempat pemandian. Pesanggrahan ini didirikan pada masa pemerintahan Sri Sultan Hamengku Buwono II (1792-1810).

\section{Pesanggrahan Rejokusumo}

Pesanggrahan Rejokusumo, terdapat di Desa Taman, Kecamatan Banguntapan, Kabupaten Bantul, Propinsi D.I.Y. Bangunan pesanggrahan ini didirikan pada masa pemerintahan Sri Sultan Hamengku Buwono VII (1877-1921). 
Bekas keberadaan bangunan pesanggrahan Rejokusumo dapat diketahui dari tinggalan bangunan yang disebut Gedong Temanten. Kondisi bangunan Gedong Temanten ini secara keseluruhan kurang terawat, banyak ditumbuhi rerumputan dan beberapa dindingnya rapuh.

\section{Pesanggrahan Ambar Binangun}

Pesanggrahan Ambar Binangun, terdapat di Dusun Kalipakis, Desa Tritonirmolo, Kecamatan Kasihan, Kabupaten Bantul, Propinsi D.I.Y. Bangunan pesanggrahan ini didirikan pada masa pemerintahan Sri Sultan Hamengku Buwono VII (1877-1921). Secara keseluruahan bangunan pesanggrahan Ambar Binangun terdiri dari beberapa komponen bangunan antara lain, taman, kolam, pendopo, pringgitan dan tempat ibadah (meditasi).

\section{Pesanggrahan Ambarukmo}

Pesanggrahan Ambarukmo, terletak di Dusun Depok, Kelurahan Depok, Kabupaten Sleman, Propinsi D.I.Y. Bangunan pesanggrahan ini didirikan pada masa pemerintahan Sri Sultan Hamengku Buwono VII (I877-1921).

Secara keseluruhan bangunan pesanggrahan Ambarukmo ini terdiri dari beberapa komponen bangunan antara lain, taman, pendopo, kolam, pringgitan dan bangunan tempat ibadah (meditasi).

\section{Pesanggrahan Bulurejo}

Pesanggrahan Bulurejo, terletak di Dukuh Pengasih, Kelurahan Pengasih, Kecamatan Pengasih, Kabupaten Kulon Progo, Propinsi D.1.Y. Bangunan pesanggrahan ini didirikan pada masa pemerintahan Sri Sultan Hamengku Buwono I (1755-1760). Komponen-komponen bangunan yang terdapat di pesanggrahan Bulurejo berupa taman, pendopo, kolam dan bekas tembok keliling.

\section{Pesanggrahan Ambarketawang}

Pesanggrahan Ambarketawang, terletak di Desa Tlogo Lor, Kelurahan Ambarketawang, Kecamatan Gamping, Kabupaten Sleman, Propinsi D.I.Y. Bangunan pesanggrahan ini didirikan pada masa pemerintahan Sri Sultan Hamengku Buwono I (1755-1760). Tinggalan bangunan kuna yang sekarang masih ada diantaranya adalah bekas tembok keliling sisi selatan, sisi barat dan sisi utara.

\section{Pesanggrahan Krapyak}

Pesanggrahan Krapyak, terletak di Dusun Krapyak, Kelurahan Panggungharjo, Kecamatan Sewon, Kabupaten Bantul, Propinsi D.I.Y. Bangunan pesanggrahan ini didirikan pada masa pemerintahan Sri Sultan Hamengku Buwono I (1755-1760). Tinggalan bangunan pesanggrahan Krapyak yang sekarang masih ada berupa sebuah bangunan panggung berlantai dua. Dahulu pada lantai atas bangunan ini digunakan 
untuk membidik binatang buruan pada saat raja sedang berburu. Di sebelah timur bangunan panggung ini terdapat bekas bangunan kolam.

\section{Pesanggrahan Sonosewu}

Pesanggrahan Sonosewu, terletak di Dusun Sonopakis Kidul, Desa Sonopakis, Kecamatan Sewon, Kabupaten Bantul, Propinsi D.I.Y. Didirikan pada masa pemerintahan Sri Sultan Hamengku Buwono III ( 1810-1811). Kondisi bekas bangunan pesanggrahan Sonopakis ini sudah rusak sehingga pada saat sekarang tinggal menyisakan bekas tembok keliling pesanggrahan yang membujur utara selatan.

\section{Pesanggrahan Tamansari}

Pesanggrahan Tamansari, terletak di Kalurahan Tamansari, Kecamatan Kraton, Kodia Yogyakarta. Didirikan pada masa pemerintahan Sri Sultan Hamengku Buwono I (1755-1760). Bangunan pesanggrahan Tamansari berfungsi sebagai tempat rekreasi, peristirahatan, religius dan juga berfungsi sebagai tempat pertahanan. Hal ini tampak antara lain dengan adanya segaran yang lengkap dengan perahunya, lorong-lorong bawah tanah, kolam pemandian dengan tempat ganti pakaian, kolam latihan berenang, ruang untuk menari, dapur dan berbagai bangunan lainnya (Djoko Sukiman, 1992/1993).

Komponen-komponen bangunan yang terdapat di pesanggrahan Tamansari, adalah sebagai berikut:

- Gerbang Kenari, bangunan ini dapat dijumpai jika masuk melalui timur dan berbentuk candi bentar.

- Gedong Temanten dan Gedong Pangunjukkan.

- Gapura Panggung, gapura ini disebut Gapura Panggung karena mempunyai panggung dan terletak di sebelah barat Gedong Temanten dan Gedong Pangunjukkan.

- Gedong Sekawan, terletak di sebelah barat Gapura Panggung. Bangunan ini mempunyai denah empat persegi panjang dengan atap berbentuk limasan.

- Kolam Umbul Winangun, merupakan kompleks bangunan yang dilengkapi dengan kolam pemandian.

- Gapura Agung, terletak di sebelah barat Kolam Umbul Winangun.

- Gerbang Carik, dahulu bangunan ini berfungsi sebagai kantor yang pada saat ini disamakan dengan sekretariatan.

- Gedong Garjitowati, terletak di sebelah selatan Gerbang Carik. Bangunan ini sekarang sudah runtuh yang tersisa hanya bagian fondasi berbentuk empat persegi panjang. 
- Gedong Taman Umbulsari, bangunan ini terletak di sebelah timur Gedong Garjitowati. Bangunan ini juga telah runtuh tinggal menyisakan bagian fondasinya saja.

- Pasarean Ledoksari, kompleks ini merupakan tempat peristirahatan atau tempat raja bermalam, keseluruhan bangunan berdenah $U$ dan pada bagian yang terbuka menghadap ke arah selatan.

- Pogangan Peksi Beri; Pogangan artinya tempat pemberhentian perahu, jadi semacam pelabuhan. Dahulu Pogangan ini merupakan tempat merapatnya perahu setelah berlayar di segaran.

- Gerbang Sumur Gumuling; Gerbang Sumur Gumuling ada dua buah yaitu gerbang barat dan timur. Gerbang barat kini hanya tinggal sisanya saja, demikian pula urung-urungnya telah runtuh sehingga tidak mungkin dapat dilewati. Sedangkan pintu yang berada di sebelah timur masih cukup baik untuk dikenali bentuknya dan urung-urung yang ada masih cukup aman untuk dapat dilewati.

- Sumur Gumuling; Bangunan Sumur Gumuling berbentuk seperti sumur yang dindingnya dibuat berongga dan bertingkat.

- Pulau Kenanga, terletak di sebelah timur Sumur Gumuling. Bangunan Pulau Kenanga merupakan sebuah bangunan bertingkat. Dari atas bangunan ini dapat dininkmati/disaksikan obyek-obyek yang berada di sekeliling Pulau Kenanga.

- Urung-Urung, bangunan ini terletak di selatan Pulau Kenanga. Keseluruhan bangunan urung-urung membujur arah utara selatan. Di tengah lorong sisi timur terdapat sebuah lorong yang menuju ke Pulau Panembung.

- Pulau Panembung, berada di sebelah selatan Pulau Kenanga. Bangunan ini dahulu berfungsi sebagai tempat raja bersemedi.

Bangunan pesanggrahan Tamansari pada saat ini telah dimanfaatkan oleh pihak pariwisata setempat, yaitu sebagai obyek wisata. Mengingat kondisi bangunan pesanggrahan ini masih cukup lengkap bagian komponen bangunannya dan letaknya berdekatan dengan obyek wisata kraton Kasultanan Yogyakarta. Sejumlah komponen bangunan yang terdapat di dalam pesanggrahan Tamansari telah direnovasi misalnya, perbaikan gapura, kompleks kolam renang dan tempat peristirahatan raja.

\section{B. Pesanggrahan-pesanggrahan di wilayah Kasunanan Surakarta}

\section{Pesanggrahan Purwodadi}

Pesanggrahan Purwodadi, terletak di Dukuh Purwotomo, Kalurahan Purwosari, Kecamatan Laweyan, Kodia Surakarta, Propinsi Jawa Tengah. Bangunan pesanggrahan ini didirikan pada masa pemerintahan Paku Buwono X.

Di dalam pesanggrahan Purwodadi terdapat komponen bangunan berupa bangunan barak-barak tentara. Bangunan pesanggrahan Purwodadi ini sekarang sudah tidak ada 
bekas-bekasnya lagi karena telah dibongkar dan di atas bekas bangunan pesanggrahan telah didirikan sebuah bangunan toko swalayan.

\section{Pesanggrahan Kebon Rojo}

Pesanggrahan Kebon Rojo, terletak di Dusun Sriwedari, Kelurahan Sriwedari, Kecamatan Laweyan, Kodia Surakarta, Propinsi Jawa Tengah. Bangunan pesanggrahan ini didirikan pada masa pemerintahan Paku Buwono X. Komponen bangunan yang ada berupa taman dan kolam.

\section{Pesanggrahan Balekambang}

Pesanggrahan Balekambang, terletak di Dusun Manahan, Kelurahan Manahan, Kecamatan Manahan, Kodia Surakarta, Propinsi Jawa Tengah. Bangunan pesanggrahan ini didirikan pada masa pemerintahan Paku Buwono X. Komponen bangunan yang terdapat di pesanggrahan Balekambang berupa kolam dan taman.

\section{Pesanggrahan Ngendromarto}

Pesanggrahan Ngendromarto, terletak di Dusun Ngaglik, Kelurahan Samiran, Kecamatan Selo, Kabupaten Boyolali, Propinsi Jawa Tengah. Bangunan pesanggrahan ini didirikan pada masa pemerintahan Paku Buwono X.

Menurut keterangan juru kunci pesanggrahan Ngendromarto bapak Kalijo (78 tahun), bangunan pesanggrahan ini dahulu menghadap ke timur berbentuk joglo yang terdiri dari bangunan pendopo, pringgitan dan dalem ageng. Namun sekarang bangunan ini sudah tidak ada lagi karena dibakar oleh TNI yang merasa kawatir apabila bangunan tersebut dijadikan sebagai tempat persembunyian tentara Belanda. Sehingga pada saat sekarang tinggal menyisakan bak penampungan air saja.

\section{Pesanggrahan Paras}

Pesanggrahan Paras, terletak di Dusun Paras, Desa Paras, Kecamatan Cepogo, Kabupaten Boyolali, Propinsi Jawa Tengah. Bangunan pesanggrahan ini didirikan pada masa pemerintahan Paku Buwono X. Komponen-komponen bangunan yang terdapat di pesanggrahan ini berupa bekas tembok keliling, kolam dan bangunan tempat ibadah.

\section{Pesanggrahan Pengging}

Pesanggrahan Pengging, terletak di Desa Pengging, Kecamatan Banyudono, Kabupaten Boyolali, Propinsi Jawa Tengah. Bangunan pesanggrahan ini didirikan pada masa pemerintahan Paku Buwono X. Tinggalan arkeologis yang tersisa berupa bekas tembok keliling sisi selatan bangunan pesanggrahan. 
Di sebelah selatan bekas bangunan pesanggrahan Pengging terdapat tinggalan arkeologis, berupa kolam renang berjumlah lima buah yang dahulu merupakan bagian dari bangunan pesanggrahan Pengging.

\section{$\mathbf{P}$} EMBAHASAN

Melihat keberadaan sejumlah bangunan pesanggrahan baik di wilayah Kasultanan Yogyakarta maupun di wilayah Kasunanan Surakarta. secara umum tampak bahwa kondisinya / kelestariannya cukup memprihatinkan dan belum sepenuhnya mendapat perhatian selayaknya. Tampak bahwa beberapa bangunan pesanggrahan yang terletak di tengah kota cenderung terlanda oleh berbagai kepentingan pembangunan, misalnya, bangunan pesanggrahan Ambarbinangun yang terdapat di wilayah Keraton Kasultanan Yogyakarta. Pesanggrahan ini dibangun pada masa Hamengku Buwono VII sekarang telah beralih fungsi sebagai tempat kegiatan kepemudaan. Dengan dibangunnya berbagai fasilitas kepemudaan di dalam bangunan pesanggrahan ini mengakibatkan hilangnya unsur unsur asli yang ada. Sebagai situs peninggalan sejarah situs bangunan asli dapat dikatakan hampir hilang. Begitu pula beberapa bangunan pesanggrahan yang terdapat di wilayah Keraton Kasunanan Surakarta seperti bangunan pesanggrahan Kebon Rojo dan pesanggrahan Bale Kambang. Sementara itu bangunan-bangunan pesanggrahan lainnya sudah hilang sama sekali dan dibiarkan terbengkalai. Berdasarkan pengamatan di lapangan ternyata pengaman Benda Cagar Budaya masih bermasalah hal ini di sebabkan karena :

- Tidak semua instansi, mengerti Benda Cagar Budaya berikut perangkat hukum yang melindunginya.

- Belum tersedianya dana yang memadai untuk kegiatan pengamanan baik preventif maupu represif.

- Kesadaran masyarakat untuk menjaga, melidungi dan memberikan keterangan yang menyangkut benda-benda yang bernilai sejarah masih rendah.

- Lokasi Benda Cagar Budaya yang jauh dari pemukiman, memungkinkan penjarah Benda Cagar Budaya melakukan aksinya.

- Terbatasnya tenaga ahli yang dapat turut serta dalam proses pengamanan secara langsung.

Selama ini belum pernah dilakukan analisis terhadap potensi sumber daya Arkeologi terhadap beberapa tingalan bangunan pesanggrahan tersebut di atas, kecuali bangunan pesanggrahan Tamansari yang terdapat di wilayah Keraton Kasultanan Yogyakarta mengingat bangunan pesanggrahan tersebut saat ini telah di manfaatkan. Meskipun demikian secara garis besar akan dicoba untuk menggambarkan nilai penting bangunan-bangunan pesanggrahan tersebut sebagai suatu sumberdaya Arkeologi. Setidak tidaknya bangunan pesanggrahan tersebut memiliki nilai penting dalam kesejarahan, ilmu pengetahuan, dan sosial ekonomi. Aspek kesejarahan adalah sejauh mana sumber daya arkeologi itu dilatar belakangi oleh peristiwa sejarah yang 
dianggap penting serta yang berkaitan secara simbolis dengan peristiwa terdahulu. Aspek ilmu pengetahuan adalah sejauh mana sumberdaya arkeologi tersebut memiliki deposit mutu serta keluasan dalam ilmu pengetahuan yang dapat mengakomodasikan kepentingan peningkatan ilmu pengetahuan dan teknologi sesuai dengan prospek masa depan. Selanjutnya aspek sosial ekonomi adalah sejauh mana peran penting sumberdaya arkeologi tersebut bagi aspek-aspek nilai dan kehidupan masyarakat misalnya, jati diri dan citra kawasan. Selain itu sejauh mana akses maupun nilai komersial sumberdaya arkeologi tersebut dalam meningkatkan pendapatan ekonomis bagi suatu tempat misalnya pariwisata yang dapat menarik wisatawan baik domistik maupun wisatawan asing. Sehingga dapat dimanfaatkan untuk meningkatkan devisa, meningkatkan pendapatan daerah dan masyarakat, menciptakan lapangan kerja serta mendorong kegiatan perekonomian pada umumnya.

Dua aspek penting pertama di atas mengacu pada ketentuan pasal 1 UU R I No. 5 / 1992 tentang Benda Cagar Budaya, sementara itu nilai penting terakhir mengacu pada analisis nilai penting yang umumnya dilakukan dalam manajemen Sumberdaya arkeologi/budaya (Schiffer \& Gummerman, 1977).

Dari segi kesejarahan, bangunan-bangunan pesanggrahan tersebut di atas memiliki nilai historis yang cukup tinggi, mengingat keberadaan bangunan-bangunan pesanggrahan merupakan aset budaya daerah. Sementara itu dari segi ilmu pengetahuan, keberadaan bangunan-bangunan pesanggrahan itu juga memiliki kualitas tersendiri, misalnya di bidang arsitektur khususnya mengenai bangunan-bangunan pesanggrahan yang berfungsi untuk pertahanan. Dengan demikian akan bermanfaat memberikan ruang dan kesempatan bagi penelitian-penelitian ilmiah sehingga dapat mendukung pengembangan berbagai disiplin ilmu seperti sejarah, arkeologi, arsitektur, antropologi budaya dan sebagainya. Di bidang sosial ekonomi tinggalan bangunan-bangunan pesanggrahan dapat dimanfaatkan untuk kepentingan pengajaran tentang sejarah kebudayaan dan arsitektur, disamping itu dapat dijadikan sektor unggulan yang dapat menarik wisatawan baik domestik maupun wisatawan asing.

Meskipun cukup penting untuk dapat dimanfaatkan dalam berbagai bidang, namun pada kenyataannya hingga saat ini kondisi bangunan pesanggrahan sebagaian besar cukup memprihatinkan. Hal ini tentunya tidak dapat dilepaskan dari fakta bahwa berbagai dampak dari pengembangan kota dan berbagai kepentingan secara tidak langsung telah mengakibatkan rusaknya bangunan-bangunan pesanggrahan.

Konsistensi pemerintah, masyarakat dan penguna kawasan masih perlu diuji mengingat beberapa bangunan peninggalan sejarah belum melakukan tindakan pelestarian. Masih banyak bangunan-bangunan pesanggrahan hanya dibiarkan terbengkalai sehingga lambat laun menjadi semkin rusak, baik karena alam maupun manusia. 
Sementara itu terdapat bangunan pesanggrahan yang sudah mulai dimanfaatkan untuk obyek wisata (Pesanggrahan Tamansari) yang terdapat di wilayah Kasultanan Yogyakarta. Namun sampai saat ini masih belum dapat dimanfaatkan secara optimal karena di dalam areal bangunan pesanggrahan masih banyak rumah-rumah penduduk baik permanen maupun semi permanen. Tidak berarti bahwa upaya-upaya penanggulangannya belum dilakukan tetapi hal itu cukup sulit untuk dilakukan mengingat rumah-rumah yang ada sudah dihuni turun temurun. Untuk memindahkan tentunya harus menyediakan lahan penganti sehingga masih masih banyak hal yang harus dijadikan bahan pertimbangan.

$\mathbf{P}$ ENUTUP

Melihat kenyataan bahwa masih cukup banyak bangunan pesanggrahan yang masih berdiri hingga saat ini meskipun dalam kondisi yang tidak terlalu baik diharapkan dapat dilakukan upaya-upaya untuk mencegah semakin turunnya kualitas sumberdaya arkeologi tersebut. Disamping itu perlu adanya langkah-langkah pengamanan antara lain dengan penyuluhan bagi kesadaran baik pada masyarakat luas, maupun pada berbagai instansi-instansi sekiranya diperlukan dan penyediaan dana yang memadai.

Untuk mencegah semakin turunnya kualitas sumberdaya arkeologi yang berupa bangunan pesanggrahan dapat dikemukakan hal-hal sebagi berikut: sebagai langkah awal tentunya perlu diupayakan inventarisasi maupun penelitian yang cukup lengkap dan menyeluruh terhadap tinggalan bangunan-bangunan pesanggrahan yang ada. Selanjutnya langkah-langkah ini hendaknya diikuti pula dengan penerbitan SK BCB sebagai pengikat bagi para penguna ataupun pengelola bangunan-bangunan tersebut.

Selain itu informasi hasil penelitian arkeologi maupun BCB (khususnya yang menyangkut bangunan pesanggrahan) belum sepenuhnya digunakan sebagai acuan dalam perencanaan pambangunan lintas sektoral di wilayah dan juga masih kurangnya pemahaman UU RI No.5/1992 dan segala ketentuan ikutannya oleh para teknokrat perencana dan pengambilan keputusan di jajaran tingkat I dan II.

Sehubungan dengan pemeliharaan dan pengamanan terhadap bangunan-bangunan pesanggrahan perlu diperhatikan hal-hal sebagai berikut;

- Laju perkembangan pembangunan dan meningkatnya berbagai dampak akibat pemekaran kota, maka sangat diperlukan adanya pengendalian.

- Untuk mencapai kondisi di atas diperlukan rencana pembangunan yang dapat menampung berbagai kepentingan dan aspirasi yang berkembang di masyarakat dan pemerintah, baik Pemerintah Pusat, Pemerintah Daerah Tingakat I, maupun Pemerintah Daerah Tingkat II. 
- Pembangunan Daerah di propinsi dalam pelaksanaannya berpedoman pada Pola Dasar Pembangunan Daerah dengan salah satu kegiatannya adalah pembangunan kebudayaan yang diupayakan untuk mengembangkan aset budaya daerah yang sekaligus menjadi aset kebudayaan nasional, dalam rangka mempertahankan eksistensi bangsa.

Dengan adanya berbagai kegiatan manusia dan pemukiman di kawasan budaya (bangunan-bangunan pesanggrahan). Maka hal-hal yang perlu diamati dan dianalisis guna menentukan strategi bagi pengembangannya adalah pengaruh terhadap visual citra kawasan. Dalam hal ini berbagai aktivitas seperti terjadi di sekitar wilayah pesanggrahan Tamansari misalnya yang hampir tertutup oleh padatnya hunian. Maka yang perlu tetap diupayakan adalah bagaimana citra visual kawasan bersejarah tidak tertutup oleh aktifitas-aktifitas yang dapat mengaburkan citra visual aslinya. Hal lain yang perlu diperhatikan adalah dampak kegiatan sosial. Kehidupan masyarakat yang semula merupakan suasana pemukiman pada umumnya, lambat laun berubah menjadi kawasan yang didominasi dengan berbagai fasilitas wisata seperti hotel, pertokoan, dengan berbagai kemungkinan ekse-ekses pengaruhnya. Hal ini menuntut diadakannya pembatasan seperlunya agar sendi-sendi kehidupan masyarakat tetap dapat ditegakkan, khususnya yang berkaitan dengan budaya tradisional di kawasan tersebut (Arya Ronald dkk, 1999). Dampak-dampak yang bersifat populatif terjadi peningkatan yang cukup tinggi dari tahun ketahun, sebagai contoh kegiatan perdagangan di sekitar pesanggrahan Tamansari yang secara langsung atau tidak langsung akan menambah beban sampah domestik kawasan sehingga secara tidak langsung akan berpengaruh pada kondisi fisik lingkungan termasuk bangunan di dalamnya. 


\section{KEPUSTAKAAN}

Schiffer, Michael B. \& George J. Gummerman. 1977. Conservation Archaeology, A Guide for Cultural Resources Management Studies. New York: Academic Press.

Soekiman, Djoko dkk. 1992/1993. Tamansari. Jakarta : Proyek Pengembangan Media Kebudayaan. Jakarta 1992/1993.

Soekanto. 1952. Sekitar Jogjakarta 1755 - 1825 (Perjanjian Giyanti - Perang Diponegoro). Djakarta/Amsterdam.

Sulendraningrat, P.S. 1978. Sejarah Cirebon. Jakarta : Departemen Pendidikan dan Kebudayaan.

Tim Studi Cipta Nindita Buana, 1999. Studi Penggalian dan Inventarisasi BendaBenda Budaya di Propinsi Daerah Istimewa Yogyakarta, Laporan Inventarisasi dan Identifikasi Benda-Benda Budaya. Yogyakarta : Departemen Pendidikan dan Kebudayaan.

Widodo, Sambung. 2001. Laporan Hasil Penelitian Arkeologi Survei PesanggrahanPesanggrahan Pada Masa Mataram Islam di D.I.Y. dan Kodia Surakarta, Propinsi Jawa Tengah (Tahap I). Balai Arkeologi Yogyakarta.

2002. Laporan Hasil Penelitian Arkeologi Survei PesanggrahanPesanggrahan Pada Masa Mataram Islam di D.I.Y. dan Kabupaten Boyolali, Propinsi Jawa Tengah. (Tahap II). Balai Arkeologi Yogyakarta.

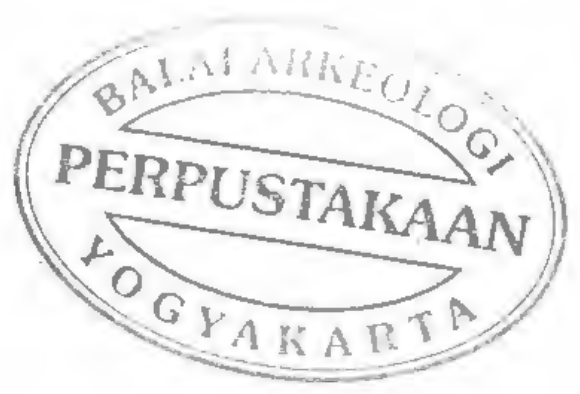

Berkala Arkeologi Th. XXIII (2) 